\title{
TEMPORAL NICHE OVERLAP OF A RIPARIAN FOREST BAT ASSEMBLAGE IN SUBTROPICAL MEXICO
}

\author{
Julio César Arriaga-Flores', IVÁn Castro- \\ Arellano ${ }^{2,3}$, Arnulfo Moreno-Valdez ${ }^{1}$ Y \\ Alfonso Correa-SANDOVAL ${ }^{1}$ \\ 1 Instituto Tecnológico de Ciudad Victoria, Boulevard Emilio Portes \\ Gil № 130, Ciudad Victoria, Tamaulipas, 87010, México \\ 2 Department of Biology, Texas State University-San Marcos, San \\ Marcos, Texas 78666, USA; \\ 3 Center for Environmental Sciences \& Engineering, University of \\ Connecticut, Storrs, CT 06269-4210, USA. \\ Autor de correspondencia: Iván Castro, ic13@txstate.edu
}

\begin{abstract}
Use of time as mediator of ecological interactions is important but has been poorly studied and has received less attention than other niche axes. We characterized and compared patterns of activity, and temporal activity overlap of a bat assemblage at a riparian forest from La Peregrina Canyon, Tamaulipas, Mexico. Bats were captured during twenty one-nights, distributed over a year, using mistnets. Nets were opened before sunset and closed $13 \mathrm{~h}$ later, being checked every $30 \mathrm{~min}$. A total of 22 species were recorded, with Sturnira lilium, Desmodus rotundus, S. Iudovici, Artibeus lituratus and Pteronotus davyi, as the most abundant species. The activity of $D$. rotundus was different from other abundant species, except with $A$. lituratus with whom had a high activity overlap. Within the assemblage, the highest temporal overlap was between S. lilium and S. Iudovici. Among common guilds, frugivores showed a different pattern from that of insectivores and sanguinivores. Although riparian zones mainly provide roost, food and water, they also provide protection along streams, therefore are used as a flight corridor. This is the first study that analyzes temporal use by neotropical bats of a riparian habitat using null model analysis with different time resolutions.
\end{abstract}

Key words: activity patterns, chiroptera, chronoecology, community structure, La Peregrina Canyon, Mexico, null models.

\section{RESUMEN}

La repartición del nicho temporal puede ser un mecanismo viable para la coexistencia de las especies, pero ha sido pobremente estudiado y recibido menor atención que otros ejes (i.e. alimento y espacio). En este estudio caracterizamos y comparamos patrones de actividad y sobrelapamiento de actividad temporal en un ensamblaje de murciélagos del bosque ripario en el cañón de La Peregrina, Tamaulipas, México. Se capturaron murciélagos durante veintiuna noches utilizando redes de niebla. Las redes se abrieron antes de la puesta del sol, se cerraron $13 \mathrm{hr}$ después, y se revisaron cada 30 
min. Se registraron un total de 22 especies, con Sturnira lilium, Desmodus rotundus, S. Iudovici, Artibeus lituratus y Pteronotus davyi, como las especies más abundantes. La actividad de D. rotundus fue diferente a la del resto de especies abundantes, con excepción de A. lituratus con quién presento el mayor sobrelapamiento de actividad. Dentro del ensamblaje, el más alto sobrelapamiento temporal fue entre S. lilium y S. Iudovici. A través de gremios tróficos, los frugívoros mostraron un patrón diferente al de insectívoros y sanguinívoros. Aunque las zonas riparias proporcionan principalmente refugio, alimento y agua, también brindan protección a lo largo de arroyos, por lo tanto son utilizadas como un corredor de desplazamiento. Este es el primer estudio que analiza el uso temporal por murciélagos neotropicales de un hábitat ripario utilizado análisis de modelo nulo con diferentes resoluciones de tiempo.

Palabras clave: patrones de actividad, Chiroptera, cronoecología, estructura de comunidades, Cañón La Peregrina, México, modelos nulos.

\section{INTRODUCTION}

Basic studies about mechanisms that lead to partitioning of resources in nature provide useful information in community ecology (Weiher and Keddy, 1999). Species coexistence is facilitated by interspecific subdivision of the three primary niche axes: food, space and time (Pianka, 1973; Schoener, 1974). Despite to exist a branch of ecology concerned in with the use of time as an ecological resource by organisms (i.e., chronoecology; Halle and Stenseth, 2000); time as a mediator axis of ecological interactions has been poorly studied (Castro-Arellano et al., 2010; Kronfeld-Schor and Dayan, 2003). In some cases ecologists have overlooked the relevance of temporal activity patterns and their effects on community dynamics (Morgan, 2004). In a temporally partitioned community, species should be able to obtain access to space or food, facilitating coexistence (Schoener, 1974), and the form in which species exploit those resources determines their temporal activity patterns (Pianka, 1973).

In natural assemblages (group of syntopic species sensu Fauth et al., 1996) all species potentially vie for resources, thus creating simultaneous interactions that need to be addressed concurrently. The use of an explicit hypothesis to evaluate patterns in the absence of a mechanism represents an advance over traditional statistical tools and one capable of detecting assemblage wide patterns (Gotelli and Graves, 1996). Recently, evidence for in- terspecific differences in activity patterns in mammalian assemblages has been explored with simulation approaches (Castro-Arellano and Lacher, 2009; Castro-Arellano et al., 2010; Presley et al., 2009a, 2009b). Previously, null models were not used to analyze activity patterns due to sequential and continuous nature of time as resource, and was required a different model of those used to evaluate discrete and non-sequential resources (Castro-Arellano et al., 2010; Gotelli and Graves, 1996).

Bats constitute the second most diverse order of mammals, they are almost exclusively nocturnal, use diverse habitats, and exploit a variety of prey, thus is possible to encounter syntopic species which potentially interact (Altringham, 1996; Kalko et al., 1996; Patterson et al., 2003). Several studies have addressed food and microhabitat use in bat assemblages (Charles-Dominique, 1991; Fleming et al., 1972; Furlonger et al., 1987; Grindal et al., 1999; Heithaus et al., 1975). However few studies have dealt with use of time, documenting or comparing temporal activity patterns of temperate (Brown, 1968; Cockrum and Cross, 1964; Kunz, 1973) or tropical bats (de Souza Aguiar and Marinho-Filho, 2004; Marinho-Filho and Sazima, 1989; Presley et al., 2009a, 2009b).

Riparian forest and river systems offer to bats: a source of water, foraging ground and roosting sites. Bats prefer riparian areas to foraging due to provide a high food resource concentration (e.g., insects and fruits; Galindo- 
González and Sosa, 2003; Grindal et al., 1999). These areas provide drinking water among lentic and lotic systems (Cross, 1988; Grindal et al. 1999).

Trees in riparian forests commonly are selected as roost sites reducing commuting distances between forest remnants or isolated trees (Estrada and Coates-Estrada, 2002; Bernard and Fenton, 2003). Thus, overall species exploit river system and surrounding riparian forest as corridors or flyways during foraging activity (Fleming et al. 1972; LaVal et al., 1977; Menzel et al., 2005).

Using different temporal resolutions, we evaluated activity patterns of five common bat species from three different guilds at a riparian corridor in subtropical Mexico. We hypothesized that (1) temporal activity patterns of species are shared within the frugivorous guild, and that (2) different guilds will show independent or segregated activities if they represent substantially different food resource use (i.e., plant vs animal food sources). Empirical data were subjected to traditional statistical comparisons and a null model analysis aimed to assess whether the temporal overlap can be more or less from what will be expected from a random expectation.

\section{MATERIALS AND METHODS}

\section{Study area}

Research was conducted in La Peregrina Canyon at east-facing slopes of the Sierra Madre Oriental, near Ciudad Victoria, Tamaulipas, Mexico. The study area is within the Area Natural Protegida Altas Cumbres (30,327 ha). This protected area includes different vegetation zones: Scrub forest, Tropical semideciduous forest, Oak forest, Pine-Oak forest, Pine forest, and Riparian forest. We established a $5 \mathrm{~km}$ transect $\left(23^{\circ} 46^{\prime} 39^{\prime \prime} \mathrm{N}, 9^{\circ} 12^{\prime} 26^{\prime \prime} \mathrm{W}\right)$ along the riparian forest following the stream "San Felipe or Los Troncones". This riparian corridor was chosen based on homogeneous habitat conditions that provided the dominance of tree species Platanus rzedowskii Nixon \& Poole, Taxodium mucronatum Ten, Cephalanthus salicifolius
Humb. \& Bonpl., Carya sp. Nutt., and Salix sp. L. (García, 2009), and the null elevational variation throughout transect extension (250 m.a.s.I). Mean annual temperature is $24{ }^{\circ} \mathrm{C}$ with little seasonal variation and mean annual precipitation ranges from $717.3 \mathrm{~mm}$ to $1058.8 \mathrm{~mm}$ with a wet season in summer (SPP, 1983).

\section{Field methods}

Sampling was conducted during twenty onenight visits at different points along transect, from March 2009 to March 2010. We collected two-night per month, except in April, June, and August to September in 2009, that only onenight per month was sampled. Bats were captured with one $12 \mathrm{~m}$ mist-net, except four nights (20\%) were we used two $12 \mathrm{~m}$ nets. The nets were always deployed over the stream, and moved $500 \mathrm{~m}$ to $1 \mathrm{~km}$ approximately at different site each night to enhance the possibility of bat captures. Nets were opened before sunset and closed $13 \mathrm{~h}$ later, being checked every $30 \mathrm{~min}$. That time lapse was considered to try sample bat species that begin their activity at hours before at dusk or hours after at sunrise, and also cover variations in night duration at each annual season. The total effort was 6,420 net-meterhours of sampling. To avoid the effects of lunar phobia (Crespo et al., 1972; Morrison, 1978) on sampling efficacy we tried to avoid netting in full moon nights. However, due to logistic limitations we had to sample during a cloudless full moon night and two clouded full moon nights. But since we always put nets under closed canopies we believe this has minor impact as lunar phobia in bats is majorly associated to open areas (Presley et al., 2009a).

For each captured individual we recorded species identity, sex, reproductive condition, age, mass, standard morphometric measurements, and time of capture. Since temporal and spatial separation among samples was considerable and since bat recaptures in mist nets is extremely uncommon, we regarded each capture as a different individual. For each species, except for Choeronycteris mexicana, a set of voucher specimens was prepared and deposited in the Colección de Vertebrados de 
Tamaulipas at the Instituto de Ecología Aplicada of the Universidad Autónoma de Tamaulipas. Species identification was facilitated by taxonomic keys in Medellín et al. (2009) and we followed the systematic recommendations of Simmons (2005) for arrangement of bat taxa. We classified species (Table 1) according to broad foraging guilds (Gardner, 1977; Willig, 1986; Wilson, 1973).

\section{Data analysis}

We characterized structural aspects of the assemblage using a variety of diversity metrics including species richness (i.e., cumulative number of species), Shannon diversity (Pielou, 1975), Camargo evenness (Camargo, 1993), Berger-Parker dominance (Berger and Parker, 1970), and rarity (i.e., number of species with a relative frequency of capture less than the inverse of species richness; Camargo, 1993; Gaston, 1994). A species accumulation curve was generated considering the nights as response units. To eliminate the influence of the order in which the nights were added, the sample was randomly 1,000 times using PAST version 2.14 (Hammer et al., 2001). To calculate the expected number of species, curve was fit via nonlinear regression procedure of Statistica program (StatSoft, 2007) using the Clench equation:

$$
S_{n}=a \cdot n /(1+b \cdot n)
$$

Where, a represents rate of increase of new species at begin sampling; $b$ is parameter related to the curve's shape; $n=$ is accumulated number of samples; and $S_{n}$ represents the expected number of species in $n$ samples. The model predicts the species richness for a sample of $x$ individuals and the value that determines when the accumulation curve achieved the asymptote, which is calculated as the ratio between the constants $a / b$ (Soberon and Llorente, 1993).

Pair-wise analysis of activity patterns and assemblage-wide overlap, for statistical and ecological reasons (Castro-Arellano et al., 2007) were restricted to the abundant species of bats (species with a relative frequency $\geq$ inverse of species richness) and common guilds: frugivores (including nectarivores), insectivores and sanguinivores (Voss and Emmons, 1996). We also did a null model overlap analysis restricted to the abundant frugivorous species to address one of our hypothesis and see if previously reported chronocoincidence among bats from this guild is a common pattern (Castro-Arellano et al., 2009; Presley et al., 2009a, $2009 \mathrm{~b})$. Also that restriction of analyses to bats of a single guild reduced capture biases associated with use of ground level mist nets (Voss and Emmons, 1996). Interspecific and interguild differences in temporal activity between each pair of abundant species, or each pair of common guilds, respectively, were evaluated with Kolmogorov-Smirnov two-sample tests (Seigel, 1956) using SPSS version 11.0 for Windows (SPSS, Chicago, Illinois). Also, we measured overlap among species and guild pairs with the Czechanowski index (Feinsinger et al., 1981). This index is symmetric, approaches zero for species that have non-overlapping activity patterns, and equals 1 for species that have identical activity patterns. The proportio-

$$
a_{j k}=\frac{\sum_{i=1}^{n} P_{i j} P_{i k}}{\sqrt{\sum_{i=1}^{n} P_{i j}^{2} P_{i k}^{2}}}
$$

nal use of time $i$ by species $\mathrm{j}$ and $\mathrm{k}$ is pij and pik respectively. If $\mathrm{n}$ time intervals are recognized, Czekanowski's index of overlap is calculated as:

Captures were pooled into $30 \mathrm{~min}, 60$ min, and 120 min intervals. We tallied the number of captures for each time interval referred to number of hours after sunset. Number of captures during each time interval represented an estimate of activity or use of that resource state by each species or guild, and was the basis of analyses. For the Kolmogorov-Smirnov two sample tests we report only results from $30 \mathrm{~min}$ analysis because outcomes were the same with the longer intervals. 


\section{Null-model simulations}

Temporal overlap among abundant species, common guilds and abundant frugivorous species was estimated via the Czechanowski index (Feinsinger et al., 1981). To facilitate comparisons based on unequal sample sizes among species and guilds, all analyses were conducted using proportional activities per interval. We used a new randomization algorithm specifically designed for temporal data termed Rosario (Castro-Arellano et al., 2010), this algorithm generate null distributions and evaluate if the amount of empirical overlap was greater or less than expected by chance. Rosario maintains the shape of the empirical distribution of activity patterns, and thus keeps most of the temporal autocorrelation of activity data, thereby restricting randomly generated patterns of activity to be biologically more realistic. In each iteration, Rosario shifts the entire activity pattern of each species a random number of time intervals for each species of the assemblage and calculates the amount of overlap in the randomly generated set of activity patterns (Castro-Arellano et al., 2010). Each randomization was iterated 1,000 times, creating a null distribution of overlap index values. Significance was determined by comparing each empirical index to the associated null distribution. Because analyses were conducted as two-tailed tests, temporal coincidence (i.e., greater temporal overlap among species) in activity can be distinguished from temporal segregation (i.e., less overlap among species). Simulations using Rosario were conducted with the program TimeOverlap (CastroArellano et al., 2010) that runs in the Windows operating system.

This program is freely available online (http://hydrodictyon.eeb.uconn.edu/people/willig/Research/activity\%20pattern.html). For all analyses, we used a of of 0.05 . Temporal overlap was evaluated using captures pooled into 30,60 and 120 min intervals.

\section{RESULTS}

\section{Assemblage structure}

We recorded 200 bats representing 22 species, 14 genera, 5 families, and 5 broad guilds. Phyllostomids were the most abundant group represented by 151 individuals, 9 species, and 5 genera (Table 1). Frugivores dominated the assemblage (115 individuals), with insectivores (49), sanguinivores (32) and nectarivores (4) being much less common. From total individuals captured, abundant species comprised 161 individuals belonging to five species, three frugivores: Sturnira lilium, S. Iudovici, Artibeus lituratus; one sanguinivore: Desmodus rotundus; and one insectivore: Pteronotus davyi (Figure 1). Species accumulative curve adjusted well to Clench's equation model (Figure 2). According to equation predictions [Sobs/(a/b)], we captured $74 \%$ of expected species.

\section{Activity patterns and temporal overlap}

Abundant species showed a heterogeneous use of time during the night (Figure 3). Interspecific differences in temporal activity occurred for 4 of 10 comparisons (Table 2). The activity pattern of $D$. rotundus was different from those of all other species, with the exception of A. lituratus. Moreover, the activity pattern of $P$. davyi was not different from any another species in the assemblage, with the exception of $D$. rotundus. The highest temporal overlap was between S. lilium and S. Iudovici, and between $D$. rotundus and $A$. lituratus (Figure 3 ). In contrast, $P$. davyi and $D$. rotundus and $A$. lituratus, respectively, had the least temporal overlap among all pair-wise comparisons. Among common guilds, frugivores showed a different activity pattern from insectivores and sanguinivores, with more activity later in the night, and a peak at midnight eight hours after sunset (Figure 4). Frugivores and sanguinivores had the greatest temporal overlap (Table 3), with an increase in activity at three hours after sunset. Assemblagewide temporal overlap was always indistinguishable from a random expectation independent 
TABLE 1. Checklist of bat species from La Peregrina Canyon, Tamaulipas, Mexico.

\begin{tabular}{|c|c|c|c|c|}
\hline $\begin{array}{l}\text { Family } \\
\text { Subfamily } \\
\text { Species }\end{array}$ & $\begin{array}{l}\text { Species } \\
\text { code }\end{array}$ & $\begin{array}{l}\text { Individuals } \\
\text { (N) }\end{array}$ & $\begin{array}{l}\text { Body } \\
\text { mass } \\
(g)\end{array}$ & Guild \\
\hline $\begin{array}{l}\text { Phyllostomidae } \\
\text { Desmodontinae } \\
\text { Desmodus rotundus }\end{array}$ & Dro & 32 & 38.2 & SAN \\
\hline $\begin{array}{l}\text { Glossophaginae } \\
\text { Choeronycteris mexicana } \\
\text { Glossophaga soricina }\end{array}$ & $\begin{array}{l}\text { Cme } \\
\text { Gso }\end{array}$ & $\begin{array}{l}1 \\
3\end{array}$ & $\begin{array}{l}17.0 \\
11.6\end{array}$ & $\begin{array}{l}\text { NEC } \\
\text { NEC }\end{array}$ \\
\hline $\begin{array}{l}\text { Stenodermatinae } \\
\text { Artibeus aztecus } \\
\text { Artibeus jamaicensis } \\
\text { Artibeus lituratus } \\
\text { Artibeus toltecus } \\
\text { Sturnira lilium } \\
\text { Sturnira ludovici }\end{array}$ & $\begin{array}{c}\text { Aaz } \\
\text { Aja } \\
\text { Ali } \\
\text { Ato } \\
\text { Ali } \\
\text { Slu }\end{array}$ & $\begin{array}{c}1 \\
8 \\
18 \\
1 \\
62 \\
25\end{array}$ & $\begin{array}{l}24.0 \\
60.7 \\
68.5 \\
20.0 \\
20.6 \\
22.2\end{array}$ & $\begin{array}{l}\text { FRU } \\
\text { FRU } \\
\text { FRU } \\
\text { FRU } \\
\text { FRU } \\
\text { FRU }\end{array}$ \\
\hline $\begin{array}{l}\text { Mormoopidae } \\
\text { Mormoops megalophylla } \\
\text { Pteronotus davyi } \\
\text { Pteronotus parnellii }\end{array}$ & $\begin{array}{l}\text { Mme } \\
\text { Pda } \\
\text { Ppa }\end{array}$ & $\begin{array}{c}6 \\
15 \\
9\end{array}$ & $\begin{array}{c}15.8 \\
8.7 \\
19.2\end{array}$ & $\begin{array}{l}\mathrm{AEI} \\
\mathrm{AEI} \\
\mathrm{AEI}\end{array}$ \\
\hline $\begin{array}{l}\text { Natalidae } \\
\text { Natalus stramineus }\end{array}$ & Nst & 1 & 5.0 & AEI \\
\hline $\begin{array}{l}\text { Molossidae } \\
\text { Nyctinomops macrotis } \\
\text { Tadarida brasiliensis }\end{array}$ & $\begin{array}{l}\text { Nma } \\
\text { Tbr }\end{array}$ & $\begin{array}{l}1 \\
2\end{array}$ & $\begin{array}{l}22.0 \\
11.0\end{array}$ & $\begin{array}{l}\mathrm{HFI} \\
\mathrm{HFI}\end{array}$ \\
\hline $\begin{array}{l}\text { Vespertilionidae } \\
\text { Eptesicus fuscus } \\
\text { Lasionycteris noctivagans } \\
\text { Lasiurus borealis } \\
\text { Lasiurus cinereus } \\
\text { Lasiurus ega } \\
\text { Lasiurus intermedius } \\
\text { Nycticeius humeralis }\end{array}$ & $\begin{array}{c}\text { Efu } \\
\text { Lno } \\
\text { Lbo } \\
\text { Lci } \\
\text { Leg } \\
\text { Lin } \\
\text { Nhu }\end{array}$ & $\begin{array}{l}1 \\
1 \\
2 \\
5 \\
1 \\
1 \\
4\end{array}$ & $\begin{array}{c}15.0 \\
14.0 \\
10.0 \\
24.6 \\
16.0 \\
19.0 \\
7.5\end{array}$ & $\begin{array}{l}\text { AEI } \\
\text { AEI } \\
\text { AEI } \\
\text { AEI } \\
\text { AEI } \\
\text { AEI } \\
\text { AEI }\end{array}$ \\
\hline
\end{tabular}

Taxonomic designations follow Simmons (2005). Body mass (average) comes from personal data. Broad guild (Wilson 1973, Gardner 1977, Willig 1986 ) . Abreviations are: AEl, aerial insectivores; SAN, sanguinivores; NEC, nectarivores; FRG, frugivores; HFI, high flying insectivores. Choeronycteris mexicana is a near threatened species (Arroyo-Cabrales and Pérez, 2008).

of group (five abundant species, three common guilds, and three abundant frugivorous species) or temporal resolution $(30,60$, and 120 min., Table 4).

\section{DISCUSSION}

\section{Species diversity}

Bat assemblage diversity from La Peregrina Canyon fits well within the usual pattern from tropical zones based on relative abundances (Figure 1), where few species are abundant and the rest are rare (Fleming et al., 1972; Kalko et al., 1996; Patterson et al., 2003; Willig, 1986). Our study area is immersed in a transitional zone of two biogeographic regions: Neotropical and Nearctic, and most of abundant species that we recorded belong to Phyllostomidae family (e.g., Sturnira lilium, Artibeus jamaicensis, Desmodus rotundus), which are habitat disturbance indicators (Medellín, 2000). Thus, dominance of these species is a possibly reflect of a combined natural and anthropogenic factors, as in similar transitional areas (Avila-Cabadilla et al., 2012; Chavéz and Ceballos, 2001; IñiguezDavalos; 1991). In our case, frugivore bats (i.e., 


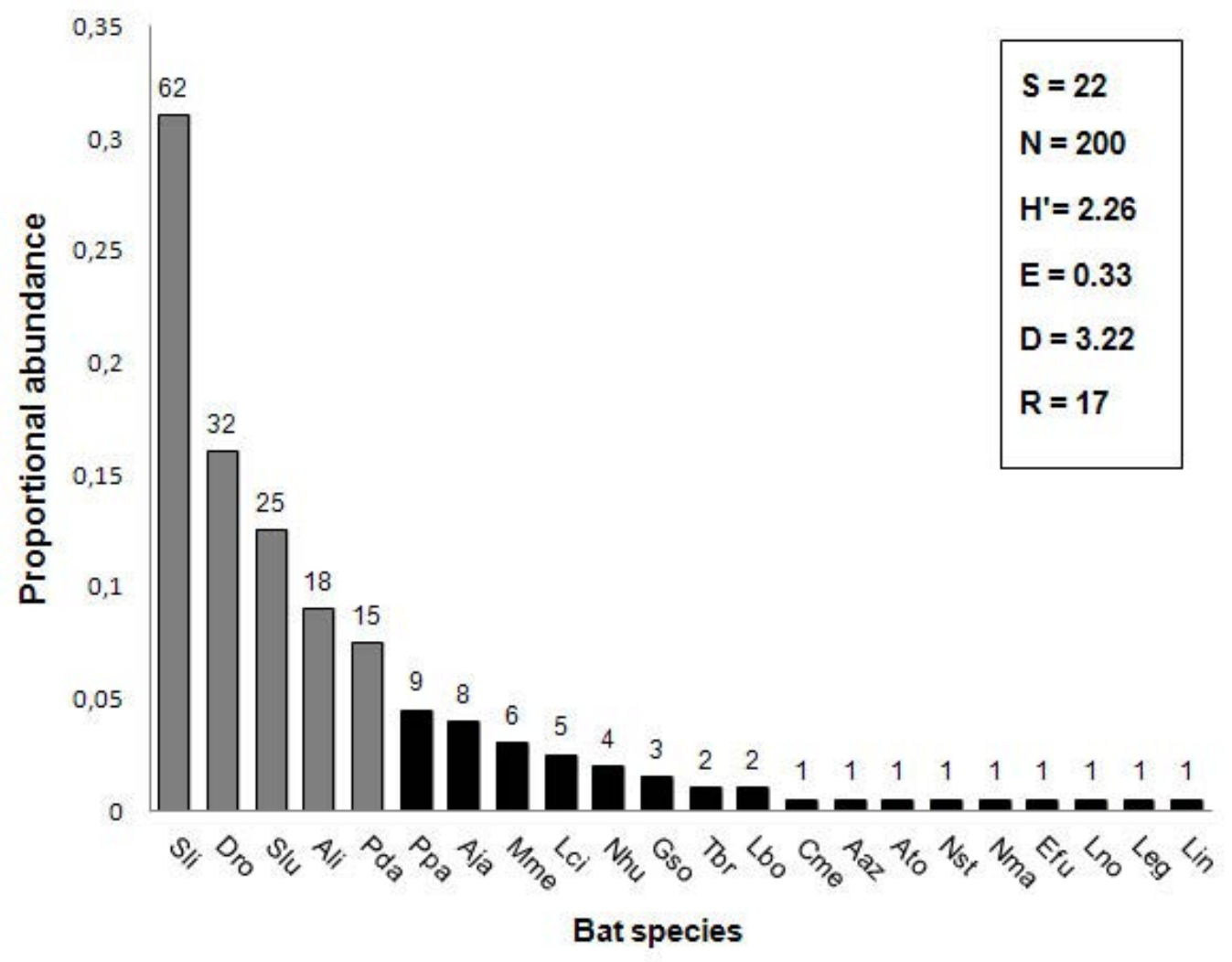

Figure 1. Species rank distribution, weighted by proportional abundance, from the riparian forest bat assemblage of La Peregrina Canyon. Dark gray bars represent abundant species (species with a relative frequency $\geq$ inverse of species richness), and black bars represent rare species (species with a relative frequency < inverse of species richness). Scores above bars represent individuals per specie. See Table 1 for species codes. Abbreviations are: $\mathbf{S}$, number of species; $\mathrm{N}$, number of individuals; H', Shannon's diversity index (Pielou, 1975); $E$, Camargo's eveness index (Camargo, 1993); D, BergerParker dominance index (Berger and Parker, 1970); and $R$, number of rare species.
Figure 2. Species accumulation curve for bat species recorded during 21 sampling nights in La Peregrina Canyon. Curve was fitted with Clench's equation model: Sobs $=22$; R2= $0.99 ; a=3.55 ; b=0.12 ; a / b$ $=29.53$.

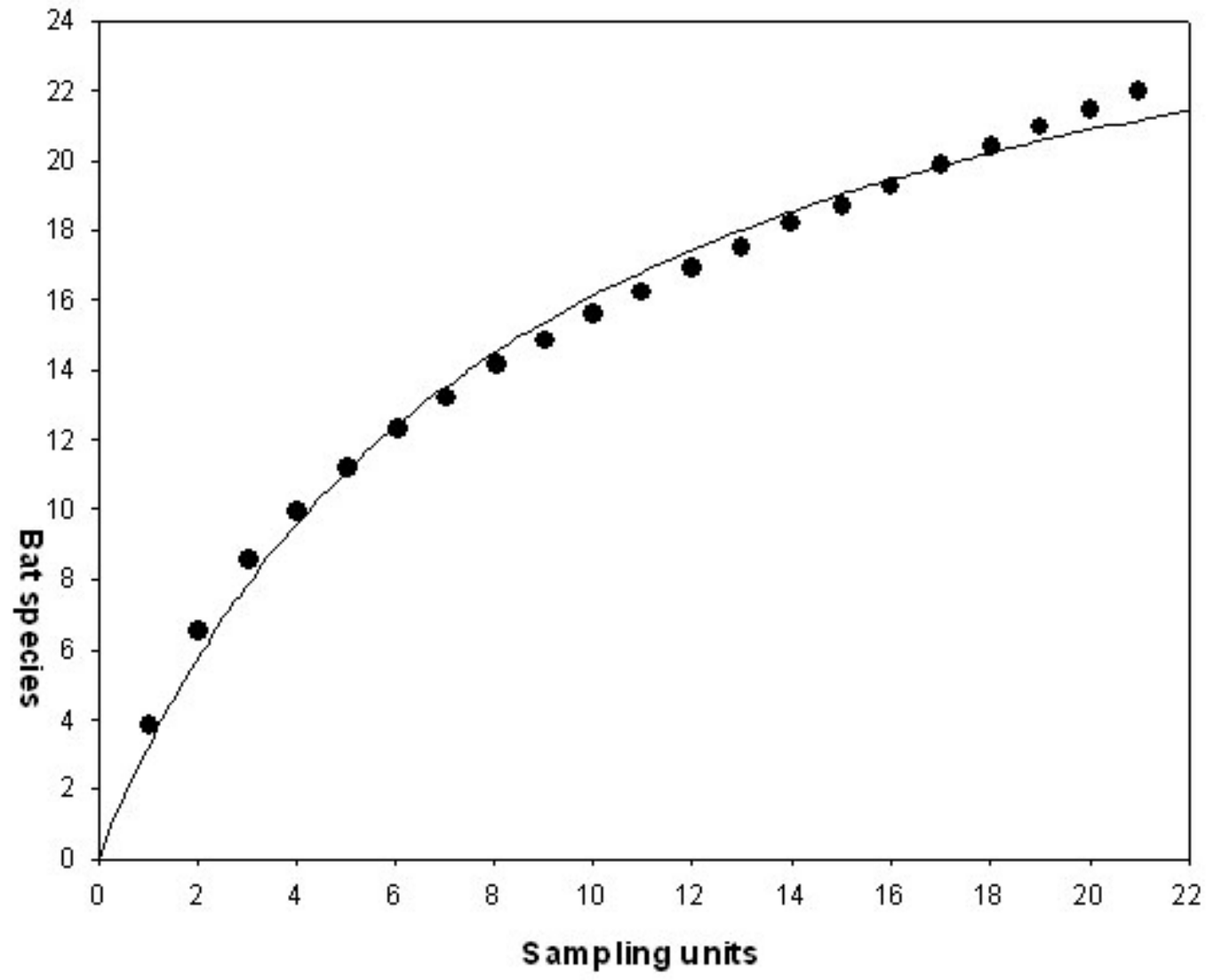


Figure 3. Patterns

of temporal activity

using 1-h night-time

intervals for each of five

abundant bat species at

the riparian forest in La

Peregrina Canyon. The

proportion of captures

at each interval is based

on all captures during

the study.

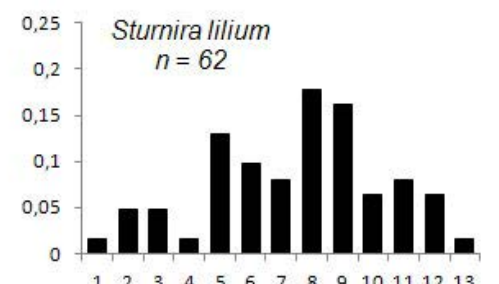

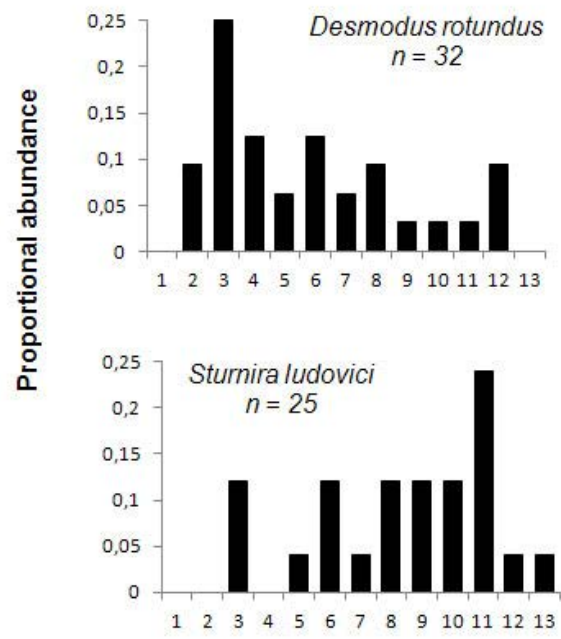

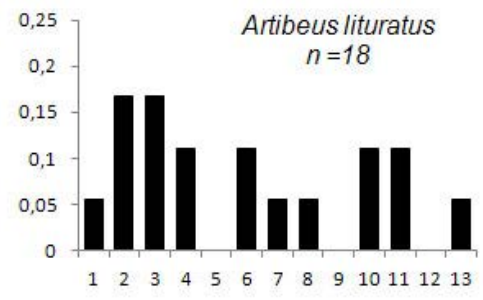

0,25 Pteronotus davyi $n=15$

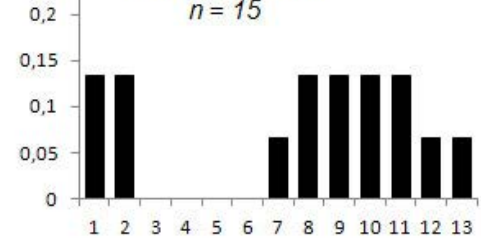

Time intervals

Table 2. Pairwise comparisons of temporal activity patterns among each of five abundant bat species at the riparian forest in La Peregrina Canyon.

\begin{tabular}{|l|c|c|c|c|c|}
\hline & & & & & \\
\hline Species & Sli & Dro & Slu & Ali & Pda \\
\hline & & & & & \\
\hline Sturnira lilium & & 0.01 & 0.34 & 0.04 & 0.61 \\
\hline Desmodus rotundus & 0.44 & & 0.01 & 0.99 & 0.05 \\
\hline Sturnira ludovici & 0.61 & 0.45 & & 0.09 & 0.52 \\
\hline Artibeus lituratus & 0.44 & 0.60 & 0.47 & & 0.14 \\
\hline Pteronotus davyi & 0.40 & 0.22 & 0.41 & 0.33 & \\
\hline
\end{tabular}

Values above the diagonal correspond to the significance of the Kolmogorov-Smirnov twosample test (Seigel, 1956) and under the diagonal correspond to Czechanowski pairwise overlap index. Temporal resolution of the analysis is $30 \mathrm{~min}$. Sample sizes are: Sli, 62; Dro, 32; Slu, 25; Ali, 18; and Pda, 15. Significance $p \leq 0.05$. Species code as in Table 1.

Table 3. Pairwise comparisons of temporal activity patterns among each of three common guilds of bat species at the riparian forest in La Peregrina Canyon.

\begin{tabular}{|l|c|c|c|}
\hline Guilds & Frugivorous & Insectivorous & Sanguinivores \\
\hline Frugivorous (FRU) & & 0.01 & 0.02 \\
\hline Insectivorous (INS) & 0.59 & & 0.28 \\
\hline Sanguinivores (SAN) & 0.52 & 0.43 & \\
\hline
\end{tabular}

Values above the diagonal correspond to the significance of the Kolmogorov-Smirnov twosample test (Seigel 1956) and under the diagonal correspond to Czechanowski pairwise overlap index. Temporal resolution of the analysis is $30 \mathrm{~min}$. Sample sizes are: FRU, 119; INS, 49; SAN, 32. Significance $p \leq 0.05$. 


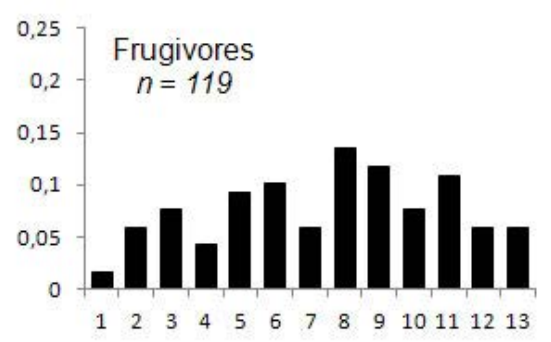

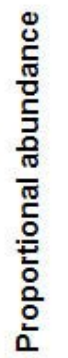
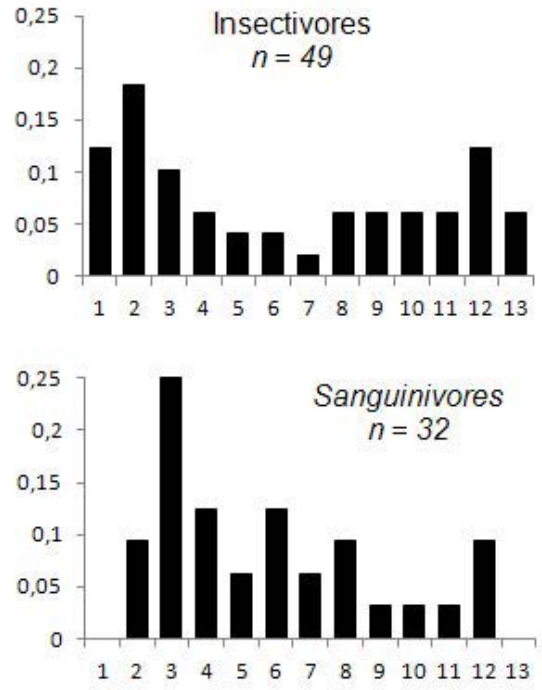

Time intervals
Figure 4. Patterns

of temporal activity using 1-h night-time intervals for each of three common guilds of bat species at the riparian forest in La Peregrina Canyon. The percentage of captures is based on all captures during the study.

Table 4. Test of assemblage-wide temporal overlap for five abundant bat species, three common guilds of bats, and three abundant frugivore species from riparian forest in La Peregrina Canyon using the Rosario algorithm randomization test.

\begin{tabular}{|c|c|c|c|c|c|c|}
\hline \multicolumn{7}{|c|}{ Czechanowski index } \\
\hline Group & $U$ & $N$ & $\begin{array}{c}\text { Temporal } \\
\text { Resolution }\end{array}$ & $\begin{array}{c}\text { Observed } \\
\text { overlap }\end{array}$ & $\begin{array}{c}\text { Mean } \\
\text { overlap }\end{array}$ & P-value \\
\hline \multirow[t]{3}{*}{ Abundant species } & & & $30 \mathrm{~min}$ & 0.442 & 0.424 & 0.227 \\
\hline & 5 & 152 & $60 \mathrm{~min}$ & 0.576 & 0.564 & 0.288 \\
\hline & & & $120 \mathrm{~min}$ & 0.635 & 0.613 & 0.222 \\
\hline \multirow[t]{3}{*}{ Common guilds } & & & $30 \mathrm{~min}$ & 0.521 & 0.528 & 0.476 \\
\hline & 3 & 200 & $60 \mathrm{~min}$ & 0.636 & 0.667 & 0.215 \\
\hline & & & $120 \mathrm{~min}$ & 0.679 & 0.677 & 0.461 \\
\hline \multirow[t]{3}{*}{ Abundant frugivores } & & & $30 \mathrm{~min}$ & 0.512 & 0.465 & 0.141 \\
\hline & 3 & 105 & $60 \mathrm{~min}$ & 0.584 & 0.569 & 0.323 \\
\hline & & & $120 \mathrm{~min}$ & 0.655 & 0.653 & 0.418 \\
\hline
\end{tabular}

$P$-values correspond to the probability of finding more overlap against a random expectation (Castro-Arellano et al. 2010). Separate analyses were conducted for 3 temporal resolution intervals (30,60 and $120 \mathrm{~min}$ ). Abbreviations are: $\mathrm{U}$, species or guilds; $\mathrm{N}$, number of individuals included in the test. 
Sturnira and Artibeus) abundance at riparian zone can be associated with presence of many plants (e.g., Piper and Ficus) that provide food resources (Avila-Cabadilla et al., 2012). High abundance of the sanguivore bat Desmodus rotundus may be due to high roost availability in riparian forest trees together with the presence of reliable food source (e.g., farm animals) in nearby human populations, thus favoring vampire bat populations (Greenhall and Schmidt, 1988).

Comparing the number of species recorded at La Peregrina with studies at riparian areas from the New World, our observations correspond well within an evident species richness latitudinal pattern (Table 5). We recorded a substantial number of species within a modest number of individuals sampled, despite great amount in number of rare species at a site, which is probably influenced by sampling effort and sampling techniques used. Maximizing number of recorded species is a priority of many bat surveys; in contrast, our aim focused on bat activity in riparian forest and thus was restricted to a microhabitat within a single vegetation type and one sampling technique (mist-nets). Our sampling method is suitable for species that use the understory, as Artibeus and Sturnira, but inefficient for species flying in canopy or above, as vespertilionids and molossids. For example, we did not record any specie of Myotis, the most diverse genus in Tamaulipas (Moreno-Valdez and VásquezFarías, 2005), although these species forage in riparian areas (Lunde and Harestad, 1986; Thomas, 1988). Additional species could have been detected with other sampling methods (i.e., bat detectors, canopy-nets; Kalko et al., 1996). However, according with the fit species accumulation curve to Clench's equation model $\left(R^{2}=0.99\right)$, our sampling is likely an adequate representation $(74 \%)$ of the bat assemblage that uses the lower portions of the riparian vegetation and thus a preliminary representation of the bat fauna for all the Area Natural Protegida Altas Cumbres (Figure 2). Using the same sampling techniques an additional effort of 21 nights would be needed to increase $1 \%$ of expected species, thus pointing out that additional sampling methods are needed to capture the whole diversity of bats in the area, an additional goal beyond out study that focused on bat activity determination.

Table 5. Diversity of 10 bat assemblages at riparian habitats from Neartic and Neotropics.

\begin{tabular}{|c|c|c|c|c|c|c|c|c|}
\hline Site & Country & Sample ${ }^{a}$ & Survey ${ }^{b}$ & $N$ & $S$ & $H^{\prime}$ & Lenghtc & Source \\
\hline Marcarena & Colombia & Hom & $\mathrm{SN}$ & 919 & 39 & 1.97 & 36 & Sánchez-Palomino et al. (1993) \\
\hline La Pacifica & Costa Rica & Hom & SN & 964 & 27 & 2.07 & 42 & Fleming et al. (1972) \\
\hline Pilón Lajas & Bolivia & Hom & $\mathrm{SN}$ & - & 25 & 2.49 & 14 & Flores-Saldaña (2008) \\
\hline La Peregrina & México & Hom & SN & 200 & 23 & 2.26 & 21 & Present study \\
\hline Belén, Rivas & Nicaragua & Hom & $\mathrm{SN}$ & 770 & 19 & 1.75 & - & Medina et al. (2004) \\
\hline Moapa Valley & USA & Het & $\mathrm{SN}, \mathrm{BD}$ & - & 15 & 1.89 & 32 & Williams et al. (2006) \\
\hline lowa & USA & Het & SN & 540 & 8 & 1.51 & - & Kunz (1973) \\
\hline Fernow & USA & Het & $\mathrm{BD}$ & $1580 d$ & 8 & 1.75 & 83 & Ford et al. (2005) \\
\hline Pilot Creek & USA & Het & $\mathrm{SN}, \mathrm{BD}$ & 207 & 7 & 1.46 & 48 & Seidman and Zabel (2001) \\
\hline Fênix & Brazil & Het & $\mathrm{SN}$ & 635 & 7 & 1.19 & 24 & Bianconi et al. (2006) \\
\hline
\end{tabular}

(a) Sample refers to sampled habitat: Het, Heterogenous; Hom, homogeneous. (b) Survey refers to used method: SN, subcanopy nets; BD, bat detector. (c) Length refers to total number of sampling nights. (d) number of bat passes recorded by bat detector. Abbreviations are: $S$, number of species; $\mathrm{N}$, number of individuals; $\mathrm{H}^{\prime}$, Shannon's diversity index. 


\section{Variation in temporal activity}

Most individuals displayed a heterogeneous use of the night. Frugivorous bats showed a trend towards the middle and later portions of the night (Figure 4). Our results for frugivores (specially genus Sturnira) showed great disparity with the pattern these species show at other neotropical sites (e.g., Brown, 1968; Castro-Arellano et al., 2009; de Souza-Aguiar and Marinho-Filho, 2004; Eckert, 1982; LaVal, 1970) where bat species tend to maintain activity throughout the night but with a marked peak in the first hours after dusk when presumably bats search or travel towards a feeding area (Marinho-Filho and Sazima, 1989; Presley et al., 2009a, 2009b).

Artibeus lituratus showed a polimodal activity pattern, with a constant presence through the night. Artibeus are regarded as canopy frugivores, fig specialists that commute relatively long distances to feeding areas (Charles-Dominique, 1991; Kalko and Handley, 2001). If captures indicate use of riparian zone as a travel corridor, our results may suggest that A. lituratus made several trips at a food patch in different times through the night (de Foresta et al., 1984; Estrada and Coates-Estrada, 2002). An alternative explanation is that this bat specie roosts in trees within the riparian area and thus encountered our nets while leaving or returning to roost sites (Estrada and Coates-Estrada, 2002; Bernard and Fenton, 2003).

In general, frugivorous bat species usually have activity peaks during the first hour after sunset (Brown, 1968; Eckert, 1982; LaVal, 1970; Marinho-Filho and Sazima, 1989), but are known to reduce their activity during the first night hours in human-created open areas (Duvergé et al., 2000; Presley et al., 2009a; Rodríguez-Duran and Lewis, 1985) or in naturally occurring openings (Fenton et al., 1994; Weinbeer and Meyer, 2006). Reduction of activity by bats in open habitats during twilight and nights with high illumination or full moon (e.g., lunarphobia, Crespo et al., 1972; Kalko and Handley, 2001; Morrison, 1978) is thought to be a response to greater predation risk by visual predators (Rodríguez-Duran and Lewis, 1985). However, at our study site the delayed activity peaks of frugivorous bats cannot be explained in terms of predation risk as it is a closed habitat under the forest canopy. We hypothesize that the pattern we found (delayed night peaks) and the pattern from other sites (earlier night peaks) represent complementary aspects of frugivorous bat activity and travel through the night. Captures are correlated with distance traveled by bats and observed patterns likely reflect times of the night when bats fly longer distances. Nets deployed inside a forest are close to foraging sites and will detect the early activity peaks created by the first foraging bout (Castro-Arellano et al., 2009; Presley et al., 2009a). On the other hand, nets deployed far from foraging areas do not record activity until later at night when bats search for new foraging areas indicating their use as travel or roost only areas (Estrada and Coates-Estrada, 2002; Fleming et al. 1972).

The insectivorous bat Pteronotus davyi seems to be most active in the first half of the night and have a second foraging bout, returning to the roost at twilight (Adams, 1989). At La Peregrina Canyon, a constant activity was detected as P. davyi likely uses the riparian corridor not only for travel but also for foraging, which often occurs along flight routes (Cross, 1988; Grindal et al., 1999; Racey and Swift; 1985). The insectivore guild activity pattern showed a bimodal activity with peaks at 2 and 12 hours after sunset. Arguably activity peaks of insectivore bats correspond to abundance peaks of crepuscular and nocturnal insects. Also, some insectivore species forage over the canopy and probably used riparian areas only to drink water. Probably differential activity patterns of insect species might reduce competition for available resources within insectivore bats by divergence in their activity (Brown, 1968; Marinho-Filho and Sazima, 1989). Although we could not test this hypothesis with our dataset since this represents a worthy test to be tried at other riparian areas or with other sampling methods (i.e., bat detectors). 
The sanguinivore bat $D$. rotundus had a unimodal activity pattern with the highest peak within the first hours of the night (03 hours after sunset), with another a slight increase two hours before twilight. Vampire bats focus their activity early in the night to travel to known food source and distribute later their activity to search other potential food sources (MarinhoFilho and Sazima, 1989). Probably we recorded early travels searching food and the peak related to day roosts return, similar as pattern described by Turner (1975).

Activity patterns may be molded by interspecific interactions or by shared constraints (Halle and Stenseth, 2000) and thus patterns of temporal overlap can provide insights on assemblage structure and resource use relationships. Just as we hypothesized, our interguild comparisons showed an assemblage-wide temporal overlap indistinguishable from a random expectation, likely a result of dissimilar foraging activity related to use of contrasting food resources (fruit/nectar, insects and blood). Previous interguild comparisons at other sites showed a high activity overlap but included guilds (gleaning insectivores, frugivores, and nectarivores) that were not as dissimilar as the ones we contrasted (Castro-Arellano et al., 2009).

However, even when temporal overlap analyses are restricted to the frugivore guild or most abundant species, we consistently found random overlap of activities, contrary to our initial hypothesis. In Amazonian lowland forests, frugivorous bats tend to exhibit considerable temporal overlap in activity, with most species showing activity peaks during the first two hours after sunset (Castro-Arellano et al., 2009; Presley et al., 2009a). Fruit is a nutrient and energypoor resource, and thus frugivorous bats that do not begin to forage early have less time to meet their considerable nightly dietary requirements as well as to devote to other vital activities (Charles-Dominique, 1986). Consequently, the need to meet daily energetic requirements may be the primary force that structures activity patterns for frugivorous bats, since they have to emerge and forage as early as possible to meet energetic demands. At secondary forests the amount of temporal overlap in activity decrease as many species of frugivorous bats are less active early in the night in open habitats likely to avoid predation risks (Presley et al., 2009a). At La Peregrina the lack of coincidental activity patterns in frugivores, and the trend towards the use of middle and latter portions of the night are likely due to the type of habitat we sampled. Previous studies have shown the distinction of activities between closed and open areas within a forest (Castro-Arellano et al., 2009; Presley et al., 2009a, 2009b) but the location of our nets was far from foraging areas and the riparian area was likely used differentially as a travel corridor due to spatial distribution of food sources on which particular bats are specialize. We support the importance of the location used to sample bat activities, which should be a strong consideration when designing and interpreting studies of temporal activities.

Despite the importance of riparian areas as bat habitat, the relation among bat activity patterns and the structure and condition of riparian areas has been poorly studied (Ciechanowski, 2002; Lloyd et al., 2006; Ober and Hayes, 2008). Riparian zones are important habitats for foraging, (Grindal et al., 1999; Racey and Swift, 1985; Vaughan et al., 1997), roost sites (Barbour and Davis, 1969; Cross, 1988; Ormsbee and McComb, 1998), and water sources (Cross, 1988) for different species and guilds of bats. Our observations at La Peregrina support the hypothesis that bats use riparian area throughout the night as a travel corridor (LaVal et al., 1977; Menzel et al., 2005), due to connectivity that provide while searching for roosts and food sources (Estrada and CoatesEstrada, 2002). The ecological features of riparian forests are not fully understood but their high potential to have significant ecological roles make them worthy of conservation and research attention. Likely they will be crucial to understand landscapes dynamics and demonstrate the suitable effectiveness of natural corridors for conservation purposes. 


\section{Acknowledgements}

We are indebted to field assistants $\mathrm{H}$. de la Rosa and A. Sánchez for the support in trapping sessions. A. Mora-Olivo provided some comments on correct tree names of riparian vegetation at La Peregrina and S. Presley provided insightful comments about the manuscript.

\section{Literature cited}

Adams, J.K. 1989. Pteronotus davyi. Mammalian Species, 346:1-5.

Altringham, J.D. 1996. Bats: Biology and Behaviour. Oxford University, Oxford.

Arroyo-Cabrales, J. and S. Pérez. 2008. Choeronycteris mexicana, in: IUCN. 2011. IUCN Red List of Threatened Species. Version 2011.2. (Downloaded on December, 2011, www.iucnredlist.org).

Avila-Cabadilla, L.D., G.A. SanchezAzofeifa, K.E. Stoner, M.Y. Alvarez-Añorve, M. Quesada and C.A Portillo-Quintero. 2012. Local and landscape factors determining occurrence of Phyllostomid bats in Tropical secondary forests. PLOS ONE, 7: e35228.

Barbour, R.W. and W.H. Davis.1969. Bats of America. University of Kentucky, Lexington. Kentucky.

Berger, W.H. and F.L. Parker. 1970. Diversity of planktonic foraminifera in deep-sea sediments. Science, 168:1345-1347.

Bernard, E. and M.B. Fenton. 2003. Bat mobility and roosts in a fragmented landscape in central Amazonia, Brazil. Biotropica, 35: 262272.

Bianconi, G.V., S.B. Mikich and W.A. Pedro. 2006. Movements of bats (Mammalia, Chiroptera) in Atlantic forest remnants in southern Brazil. Revista Brasileira de Zoologia, 23:11991206.

Brown, J.H. 1968. Activity patterns of some neotropical bats. Journal of Mammalogy, 49:754-757.

Camargo, J.A. 1993. Must dominance increase with the number of subordinate species in competitive interactions? Journal of Theoretical Biology, 161:537-542.

Castro-Arellano, I. and T.E. Jr. Lacher. 2009. Temporal niche segregation in two rodent assemblages of subtropical Mexico. Journal of Tropical Ecology, 25:593-603.

Castro-Arellano, I., S.J. Presley, L.N. Saldanha, M.R. Willig and J.M. Wunderle. 2007. Effects of low-intensity logging on bat biodiversity in Terra Firme forest of lowland Amazonia. Biological Conservation, 138:269-285.

Castro-Arellano, I., S.J. Presley, M.R. WiIlig, J.M. Wunderle and L.N. Saldanha. 2009. Reduced-impact logging and temporal activity of understorey bats in lowland Amazonia. Biological Conservation, 142:2131-2139.

Castro-Arellano, I., T.E. Jr. Lacher, M.R. Willig and T.F. Rangel. 2010. Assessment of assemblage-wide temporal niche segregation using null models. Methods in Ecology and Evolution, 1:311-318.

Charles-Dominique, P. 1986. Inter-relations between frugivorous vertebrates and pioneer plants: Cecropia, birds and bats in French Guyana. Pp. 119-135, in: Frugivores and seed dispersal (A. Estrada and T.H. Fleming, eds.). Junk, Dordrecht, Netherlands.

Charles-Dominique, P. 1991. Feeding strategy and activity budget of the frugivorous bat Carollia perspicillata (Chiroptera: Phyllostomidae) in French Guiana. Journal of Tropical Ecology, 7:243-256.

Chavéz, C. and G. Ceballos. 2001. Diversidad y abundancia de murciélagos en Selvas secas de estacionalidad contrastante en el oeste de México. Revista Mexicana de Mastozoología, 5:27-44.

Ciechanowski, M. 2002. Community structure and activity of bats (Chiroptera) over different water bodies. Mammalian Biology, 67:276-285.

Cockrum, E.L. and S.P. Cross. 1964. Time of bat activity over waterholes. Journal of Mammalogy, 45:635-636.

Cross, S.P. 1988. Riparian systems and small mammals and bats. Pp. 93-112, in: Streamside management: riparian wildlife and forestry interactions (K.J. Raedeke, ed.). Institute of Forest Resources, University of Washington, Seattle, Washington.

Crespo, R.F., S.B. Linhart, R.J. Burns and G.C. Mitchell. 1972. Foraging behavior of the common vampire bat related to moonlight. Journal of Mammalogy, 53:366-368.
De Souza-Aguiar, L.M. and J. MarinhoFilho. 2004. Activity patterns of nine phyllostomid bat species in a fragment of Atlantic Forest in southeastern Brazil. Revista Brasileira de Zoologia, 21:385-390.

De Foresta, H., P. Charles-Dominique, C. Erard and M.F. Prevost. 1984. Zoochorie et premiers stades de la régéneration naturelle aprés coupe en forât Guyanaise. Rev. Écol.-Terre Vie, 39:369-400.

Duvergé, P.L., G. Jones, J. Rydell and R.D. Ransome. 2000. Functional significance of emergence timing in bats. Ecography, 23:32-40.

Eckert, H.G. 1982. Ecological aspects of bat activity rhythms. Pp. 201-242, in: Ecology of bats (T.H. Kunz, ed.). Plenum, New York.

Estrada, A. and R. Coates-Estrada. 2002. Bats in continuous forest, forest fragments, and in an agricultural mosaic habitat island at Los Tuxtlas, Mexico. Biological Conservation, 2:237-245.

Fauth, J.E., J. Bernardo, W. Camara, J. Reserarits, J. Van Buskirk, and S.A. Mccollum. 1996. Simplifying the jargon of community ecology: a conceptual approach. American Naturalist 147:282-286.

Feinsinger, P., E.E. Spears and R.W. Poole. 1981. A simple measure of niche breadth Ecology, 62:27-32.

Fenton, M.B., I.L. Rautenbach, S.E. Smith, C.M. Swanepoel, J. Grosell and J. Van Jaarsveld. 1994. Raptors and bats: threats and opportunities. Animal Behavior, 48:9-18.

Fleming, T.H., E.T. Hooper and D.E. Wilson. 1972. Three Central American bat communities: structure, reproductive cycles, and movement patterns. Ecology, 53:555-569.

Flores-Saldaña, M. 2008. Estructura de las comunidades de murciélagos en un gradiente ambiental en la Reserva de la Biosfera y tierra comunitaria de origen Pilón Lajas, Bolivia. Mastozoología Neotropical, 15:309-322.

Ford, W.M., M.A. Menzel, J.L. Rodriguez, J.M. Menzel and J.B. Johnson. 2005: Relating bat species presence to simple habitat measures in a central Appalachian forest. Biological Conservation, 126:528-539.

Furlonger, C.L., H.J. Dewar and M.B. Fenton. 1987. Habitat use by foraging insectivorous bats. Canadian Journal of Zoology, 65:284-288. 
Galindo-González, J. and V.J. Sosa. 2003. Frugivorous bats in isolated trees and riparian vegetation associated with human-made pastures in fragmented tropical landscape. Southwestern Naturalist, 48: 579-589.

García, J. 2009. Cañón La Peregrina: Guía de Campo para identificar tipos de Vegetación. Instituto Tecnológico de Ciudad Victoria. Tamaulipas, México.

Gardner, A.L. 1977. Feeding habits. Pp. 293-350, in: Biology of Bats of the New World, Family Phyllostomatidae (R.J. Baker, J.K.Jr. Jones and D.C. Carter, eds.). Texas Tech University, Lubbock, Texas.

Gaston, K.J. 1994. Rarity. Chapman and Hall, London.

Gotelli, N.J. and G.R. Graves. 1996. Null models in ecology. Smithsonian Institution, Washington, D.C.

Greenhall, A.M. and U. Schmidt. 1988. Natural history of vampire bats. C.R.C. Press, Florida.

Grindal, S.D., J.L. Morissett and R.M. Brigham. 1999. Concentration of bat activity in riparian habitats over an elevational gradient. Canadian Journal of Zoology, 77:972-977.

Halle, S. and N.C. Stenseth. 2000. Activity patterns in small mammals, an ecological approach. Ecological Studies, 141. Springer, Berlin.

Hammer, O., D.T.A. Harper and P.D. Ryan. 2001. PAST: paleontological statistics software package for education and data analysis. $\mathrm{Pa}$ laeontologia Electronica, 4:1-9.

Heithaus, E.R., T.H. Fleming and P.W. Opler. 1975. Foraging patterns and resource utilization in seven species of bats in a seasonal tropical forest. Ecology, 56:841-854.

Iñiguez-Dávalos, L.I. 1993. Patrones ecológicos de la comunidad de murciélagos de la Sierra de Manantlán, Jalisco. Pp. 355-370, in: Avances en el estudio de los mamíferos de México (R. Medellín and G. Ceballos, eds.). Asociación Mexicana de Mastozoología, A.C. Publicaciones especiales, Vol. 1. México, D.F.

Johnson, J.B., J.W. Edwards, W.M. Ford, and M.A. Menzel. 2010. Bat community structure within riparian areas of northwestern Georgia, USA. Folia Zool., 59:192-202.
Kalko, E.K.V. and C.O. Handley Jr. 2001. Neotropical bats in the canopy: diversity, community structure, and implications for conservation. Plant Ecology, 153:319-333.

Kalko, E.K.V., C.O. Handley Jr., and D. Handley. 1996. Organization, diversity, and longterm dynamics of a Neotropical bat community. Pp. 503-553, in: Long-Term Studies in Vertebrate Communities (M. Cody and J. Smallwood, eds.). Academic, Los Angeles, California.

Kronfeld-Schor, N. and T. Dayan. 2003. Partitioning of time as an ecological resource. Annual Review of Ecology and Systematics, 34:153-181.

Kunz, T.H. 1973. Resource utilization: temporal and spatial components of bat activity in Central lowa. Journal of Mammalogy, 54:14-32.

LaVal, R.K. 1970. Banding and activity periods of some Costa Rican bats. Southwestern Naturalist, 15:1-10.

LaVal, R.K., R.L. Clawson, M.L. LaVal and W. Caire.1977. Foraging behavior and nocturnal activity patterns of Missouri bats, with emphasis on the endangered species Myotis grisescens and Myotis sodalis. Journal of Mammalogy, 58:592-599.

Lloyd, A., B. Law, and R. Goldingay. 2006. Bat activity on riparian zones and upper slopes in Australian timber production forests and the effectiveness of riparian buffers. Biological Conservation, 129:207-220.

Lunde, R.E. and A.S. Harestad. 1986. Activity of little brown bats in coastal forests. Northwest Science, 60:206-09.

Marinho-Filho, J.S. and I. Sazima. 1989. Activity patterns of six phyllostomid bat species in southeastern Brazil. Revista Brasileira de Zoologia, 49:777-782.

Medellín, R.A., H.T. Arita and O. Sánchez. 2009. Identificación de los murciélagos de México. Claves de campo. Asociación Mexicana de Mastozoología, A.C. México.

Medellín, R.A., M. Equihua and M.A. Amín. 2000. Bat diversity and abundance as indicator of disturbance in Neotropical rainforest. Conservation Biology, 14:1666-1675.

Medina, A., C.A. Harvey, D. Sánchez, S. Vilchez and B. Hernández. 2004. Diversidad y composición de chiropteros en un paisaje fragmentado de bosque seco en Rivas, Nicaragua. Encuentros, 68:24-43.

Menzel J.M., W.M. Ford, M.A. Menzel, T.C. Carter, J.E. Gardner, J.D. Garner, and J.E. Hoffman. 2005. Summer habitat use and homerange analysis of the endangered Indiana bat Journal of Wildlife Management, 69:430-436.

Moreno-Valdez, A. and E. Vásquez-Farías. 2005. Los mamíferos terrestres de Tamaulipas Pp. 213-219, in: Biodiversidad Tamaulipeca (L. Barrientos, A. Correa, J. Horta and J. García, eds.). Dirección General de Educación Superior Tecnológica. Instituto Tecnológico de Ciudad Victoria. Tamaulipas, México.

Morgan, E. 2004. Ecological significance of biological clocks. Biological Rhythm Research, 35:3-12.

Morrison, D.W. 1978. Lunarphobia in a neotropical fruit bat, Artibeus jamaicensis (Chiroptera: Phyllostomidae). Animal Behaviour, 26:852-855.

Ober, H.K. and J.P. Hayes. 2008. Influence of vegetation on bat use of riparian areas at multiple spatial scales. Journal of Wildlife Management, 72:396-404.

Ormsbee, P.C. and W.C. McComb. 1998 Selection of day roosts by female long-legged Myotis in the central Oregon cascade range. Journal of Wildlife Management, 62:596-603.

Patterson, B.D., M.R. Willig and R.D. Stevens. 2003. Trophic strategies, niche partitioning, and patterns of ecological organization. Pp. 536579, in: Bat Ecology (T.H. Kunz and M.B. Fenton, eds.). University of Chicago, Chicago.

Pianka, E.R. 1973. The structure of lizard communities. Annual Review of Ecology, Evolution, and Systematics, 4:53-74.

Pielou, E.C. 1975. Mathematical ecology. Wiley, New York.

Presley, S.J., M.R. Willig, I. Castro-Arellano and S.C. Weaver. 2009a. Effects of habitat conversion on temporal activity patterns of phyllostomid bats in lowland Amazonian rainforest. Journal of Mammalogy, 90:210-221.

Presley, S.J., M.R. Willig, L.N. Saldanha, J.M. Wunderle and I. Castro-Arellano. 2009b. Reduced-impact logging has little effect on tem- 
poral activity of frugivorous bats (Chiroptera) in lowland Amazonia. Biotropica, 41:369-378.

Racey, P. and S.M. Swift. 1985. Feeding ecology of Pipistrellus pipistrellus (Chiroptera, Vespertilionidae) during pregnancy and lactation. I. Foraging behavior. Journal of Animal Ecology, 54:205-215.

Rodríguez-Duran, A. and A.R. Lewis. 1985. Seasonal predation by merlins on sooty mustached bats in western Puerto Rico. Biotropica, 17:71-74.

Sánchez-Palomino, P., P. Rivas-Pava and A. Cadena. 1993. Composición, abundancia y riqueza de especies de la comunidad de murciélagos en bosques de galería de la Serranía de la Macarena (Meta-Colombia). Caldasia, 17:301312.

Schoener, T. W. 1974. Resource partitioning in ecological communities. Science, 185:27-39.

Seidman, V.M. and C.J. Zabel. 2001. Bat activity along intermittent streams in northwestern California. Journal of Mammalogy, 82:738-747.

Seigel, S. 1956. Nonparametric statistics for behavioral sciences. McGraw-Hill Book Company, New York.
Simmons, N.B. 2005. Order Chiroptera. Pp. 312-529, in: Mammal species of the world: a taxonomic and geographic reference (D.E. Wilson and D.M. Reeder, eds.). Johns Hopkins University, Baltimore, Maryland.

SPP (Secretaría de Programación y Presupuesto). 1983. Síntesis geográfica del estado de Tamaulipas. Instituto Nacional de Estadística, Geografía e Informática. México, D.F.

StatSoft, Inc. 2007. STATISTICA (data analysis software system), version 8.0. www. statsoft.com.

Soberón J., and J. Llorente. 1993. The use of species accumulation functions for the predictions of species richness. Conservation Biology, 7:480-488.

Thomas, D.W. 1988. The distribution of bats in different ages of Douglas fir forests. Journal of Wildlife Management, 52:619-28.

Turner, D.C. 1975. The vampire bat, a field study in behavior and ecology. John Hopkins University, Baltimore, Maryland.

Vaughan, N., G. Jones and S. Harris. 1997. Habitat use by bats (Chiroptera) assessed by means of a broad-band acoustic method. Journal of Applied Ecology, 34:716-730.

Voss, R.S. and L.H. Emmons. 1996. Mammalian diversity in neotropical lowland rainforests: a preliminary assessment. Bulletin of the American Museum of Natural History, 230:1-115.

Weiher, E. and P. Keddy. 1999. Ecological assembly rules: perspectives, advances, retreats. Cambridge University, Cambridge, England.

Weinbeer, M. and C.F.J. Meyer. 2006. Activity pattern of the trawling phyllostomid bat, Macrophyllum macrophyllum, in Panamá. Biotropica, 38:69-76.

Williams, J.A., M.J. O'farrell and B.R. Riddle. 2006. Habitat use by bats in a riparian corridor of the Mojave Desert in southern Nevada. Journal of Mammalogy, 87:1145-1153.

Willig, M. R. 1986. Bat community structure in South America: a tenacious chimera. Revista Chilena De Historia Natural, 59:151-168.

Wilson, D.E. 1973. Bat faunas: a trophic comparison. Systematic Zoology, 22:14-29. 